\title{
NEW JERSEY INTELLECTUALS AND THE UNITED STATES CONSTITUTION
}

\author{
BY MAXINE N. LURIE
}

Dr. Lurie works in the Department of Special Collections and Archives, Rutgers University Libraries and teaches in the History Department

$\mathrm{N}$ EW JERSEY was the third state to ratify the United States Constitution. Moreover the process was quick, and the vote in the Ratifying Convention was unanimous. Historians have noted little discussion either of political philosophy or the specific document in the state, pointing to a dearth of the rich newspaper and pamphlet literature found elsewhere (particularly in the neighboring state of New York where the debate was vigorous and the outcome close). But a look at the relationship between four New Jersey "intellectuals" and the Constitution reveals that this is not an entirely accurate assessment. New Jersey politicians and authors both considered and responded to current events-including the question of whether the Constitution should be ratified or not. The four men to be discussed in this paper participated in the debate over the Constitution on a number of different levels and in different ways. One wrote directly on the Constitution, the other three on contemporary political issues. Although none of their comments, essays, or pamphlets, had the impact of the Federalist Papers they remain important in understanding the ideas of the times; their existence and quantity may surprise, and certainly should please, New Jersey historians.

The four men selected for examination were not chosen because they were "representative" citizens of New Jersey. They are not even "representative" politicians, each having achieved in his own way an unusual measure of importance. William Livingston, William Paterson, John Stevens, Jr. (or "Colonel" to distinguish him from his father and grandfather of the same name), and John Witherspoon were college educated in an age when that was a mark of distinction, had inquiring minds, and as "intellectuals" continued to value learning throughout their lives. They were "Whigs" during the American Revolution, and authored, at some time in their careers, various essays and pamphlets. All four participated in the debate over the Constitution either before, during, or after the Constitutional Convention. In fact Livingston and Paterson represented New Jersey in Philadelphia, while Witherspoon sat as a member of the 
Ratifying Convention in Trenton, where Stevens' father presided over the sessions. ${ }^{1}$ Reflecting the sentiments of the state, all four strongly favored the new document. An examination of their backgrounds, political ideas, writings, and comments on the Constitution make clear why this was the case.

\section{Livingston}

William Livingston was born into one of the wealthiest merchant and landowning families in New York. Educated at Yale, he spent a long legal apprenticeship under the tutelage first of James Alexander (with whom he quarrelled) and then of William Smith, Sr., two of New York's foremost lawyers. Although never enamored with the law, he developed a sizable legal practice, and attracted a number of students to his office. Remembering his unhappy experiences as a law clerk, Livingston resolved to reform the course of study to include geography, history, rhetoric, and other subjects to "make a compleat Lawyer" and more perfect "Scholar.", He continued his own studies throughout his life and accumulated in the process a library that contained, at his death, over 500 volumes dealing with law, political theory, history, literature, and science. He also acquired a knowledge of Dutch, Latin, and French, as well as a great deal of skill in writing English. For all of his learning, Livingston did not achieve renown as a scholar, but rather as a "lawyer, man of letters, politician, educator, statesman, and, above all, [an] inveterate pamphleteer."3

Colonial New York was politically divided for most of its history, and in the mid-eighteenth century its political disagreements were fought out

' Robert R. Livingston of New York, Colonel John's brother-in-law, was also a member of the Philadelphia Convention and a strong supporter of the Constitution. Particularly interesting is his letter to John Stevens, Sr., December 8, I 787, in Archibald D. Turnbull, John Stevens: an American Record (New York, 1928), 88-89.

${ }^{2}$ Milton M. Klein, "The Rise of the New York Bar: the Legal Career of William Livingston," in David H. Flaherty ed., Essays in the History of Early American Law (Chapel Hill, I 969), 415. Livingston's lifelong support for liberal education was clearly stated in 1758 when he urged a young relative, Peter Livingston, to remain in college and study the classics because this enabled one to learn "the Art of War without the Danger of falling in Battle, the General History of Mankind without the Trouble of stirring out of our Closet and the Rudiments of Civil Policy without the risque of an Insurrection or revolt." Dorothy R. Dillon, The New York Triumvirate: A Study of the Legal and Political Careers of William Livingston, John Morin Scott, William Smith, Jr. (New York, I 949), 23.

${ }^{3}$ Milton M. Klein, The American Whig: William Livingston of New York (Columbia University Ph.D. thesis, 1954), iii (my italics); ibid., 203-204, 2 I 7. Between I 747-1 770 Livingston was associated with the publication of 16 pamphlets; Michael L. Levine, The Transformation of a Radical Whig Under Republican Government (Rutgers University Ph.D. thesis, 1975), 9. 
by two factions which coalesced around the rival Livingston and DeLancey families. As a young man William Livingston became deeply involved in this political warfare, joining with two of his friends to form what became known as the "triumvirate." They used their pens to fight their battles, and Livingston was the ringleader. In addition to writing for existing newspapers, and pamphlets, they created The Independent $R e^{-}$ flector (1752-1753) to expound their views, including the idea that the college about to be established in the colony (King's College, now Columbia University) should be a nondenominational, rather than Anglican, institution in order to protect religious freedom; that judges should be independent, and the right to trial by jury maintained. In I 768 Livingston strenuously opposed the creation of an American bishopric. All in all, an enormous amount of literature on political and religious issues flowed from Livingston's pen in the period before the Revolution.

Livingston objected to the Stamp Act on constitutional grounds and thought the colonists should seek a remedy through the moderate means of petitions, and addresses. He was taken aback by the activities of the Liberty Boys in this crisis and those that followed. In I 772 he decided to retire to the bucolic peace of farm life in Elizabethtown, New Jersey, where he built a homestead called Liberty Hall. Both retirement and peace eluded Livingston. He was soon representing New Jersey in the Continental Congress, chosen brigader general of the militia, and then elected governor of the state (and re-elected every year from 1776 until his death in 1790 ).

Livingston was regarded as a leading radical by the British who, during the course of the Revolution, put a price on the head of this "damned rebel governor," and made it unsafe for him to linger in any one place for very long. Despite his constant movement there was no letup of his literary efforts, and he has been coupled with Thomas Paine for his efforts in urging his countrymen to continue their fight. ${ }^{4}$ After the war Livingston continued to serve his state and to write for the newspapers. During the critical period he turned his attention to the evils of paper money, disapproved when the New Jersey legislature refused to pay its requisitions to the Confederation government, and thought the state needed a stronger executive and the nation a stronger government.

Livingston was one of five delegates sent to the Philadelphia Convention by New Jersey. In I 774 John Adams had described him as a "plain man" reputed to be "no public speaker, but very sensible and learned and a ready writer"; in 1787 William Pierce echoed this assessment:

${ }^{4}$ Klein, American Whig, 7 10-7 I I. 


\section{William Livingston}

Special Collections and Archives Rutgers University Libraries

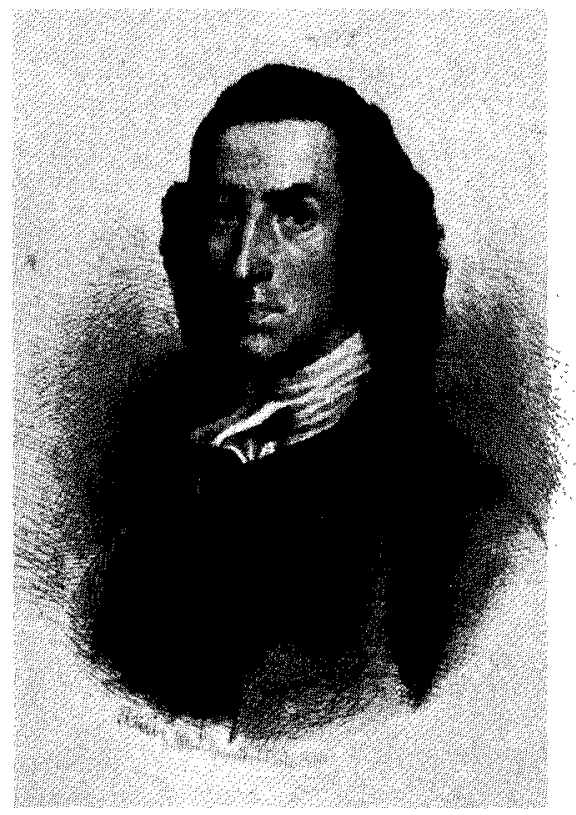

Governor Livingston is confessedly a Man of the first rate talents, but he appears to me rather to indulge a sportiveness of wit than strength of thinking. He is however equal to anything, from the extensiveness of his education and genius. His writings teem with satyr and a neatness of style. But he is no Orator, and seems little acquainted with the guiles of policy. ${ }^{5}$

In Philadelphia he quietly served on a number of committees, but did not distinguish himself in the debates. In the ratifying process in the state, though, he took a stand strongly in favor of the Constitution.

In his political philosophy Livingston was consistent. Like the other three men examined here, he was a "conservative revolutionary."6 For religious freedom, against both British "tyranny" and popular "licen-

s Robert W. Kean, William Livingston (np, 1962), np. Thomas Jones, the New York jurist and Tory, was more critical, describing Livingston to the British as a "sensible, cunning, shrewd fellow; well versed in the law, though a very indifferent speaker" who was "satirical and abusive in his writings," violent, bigoted in religion, with uncouth manners, and possessing "a savage persecuting spirit." Dillon, I6; Klein, American Whig, 237.

"One historian, putting Jefferson and Adams on a line going from left to right, placed Livingston in the center between the two; Harold W. Thatcher, "The Political Ideas of New Jersey's First Governor," Proceedings of the New Jersey Historical Society (PNJHS) v.60 (I 942), I99. While Thatcher is right here, he needs to be read with great care because he confused the writings of Col. John Stevens and Livingston. 
tiousness," he dragged his feet on the matter of independence; 7 but once that question was resolved, he was an ardent supporter of the American cause, with little patience for Tories or those who wanted to stay "neutral." He opposed both absolute monarchy and pure democracy, favoring a mixed and balanced government where rights were respected but rule was by the aristocracy. ${ }^{8}$ He maintained that the "true son of liberty" would "think it his duty to oppose every bad measure, whether attempted by prince or people."

A wealthy man, Livingston assumed that government was devised by men to protect property as well as liberty. The rampant inflation of the war years as well as the drastic depreciation of paper money then, and in the years that followed, placed him in straightened circumstances. Personal experience reinforced by political preference led him to use his pen against the resumption of paper money in a series of essays written in I 786; these show his style of writing, his ideas, and his reasons for supporting the Constitution. ${ }^{10}$ Also present is the same stinging satire that he had used thirty years earlier in New York controversies. One piece was a letter from a poor widow ruined because money owed her late husband was either not paid or repaid in depreciated currency; it ended with the lament: "will there never be an end of this paper currency, that seems contrived to ruin poor widows and orphans." I Another essay was designed as a petition asking for paper money without limits or strings attached and signed by, among others, Amos Spendthrift, Josiah Workless, John Tippler, Peter Holiday, Simon Dreadwork, Hezekiah Dolittle, and David Neverpay. ${ }^{12}$ Livingston argued that paper money would always depreciate, that it was merely a way of transferring money from those who were frugal and industrious to those who were not, that it discouraged immigration, encouraged wives and daughters to wear unnecessary

\footnotetext{
7 New Jersey replaced its delegates to the Continental Congress, including Livingston, just before Independence was voted upon with those more amenable to the idea. Livingston apparently wanted to wait until Americans were sure of assistance from France. See Theodore Sedgwick, Jr., A Memoir of the Life of William Livingston (New York, I 853), I 85; Klein, American Whig, 534-536, 553, 569, 695-696, 707.

${ }^{8}$ Livingston thought in terms of an aristocracy based on worth and merit rather than birth; see Harold W. Thatcher, "The Social and Economic Ideas of New Jerseys' First Governor," PNJHS v.6o (1942), 23 I-232. Also Levine, 31.

${ }_{9}^{9}$ Levine, 30.

10 Livingston also expressed his opposition to paper money in essays written in 1780 and I78 I. See Letter to the Legislature of New Jersey by Scipio, New Jersey Gazette, October 25 , I 780; and Letter to Mr. Collins by Scipio, New Jersey Gazette, April 25, I78I.

"Primitive Whig \#6, New Jersey Gazette, February I 3, 1786.

${ }_{12}$ Primitive Whig \#3, New Jersey Gazette, January 23, 1786.
} 
"foppery and finery," and was a plot by those who were "unconscionable, prevaricating, double-minded, [and] insidious." ${ }_{13}$

For Livingston, the mid-I 780 s had brought American glory to a low point, "marred, obscured, contaminated, and trampled in the dust, by our conduct since the illustrious era of our emancipation from British bondage." Men were not willing to pay taxes, worked two days a week receiving "double the wages" they really earned and then squandered their "non-earnings" in tippling houses. Women paid for French dancing masters when they should be home spinning. They were all "ingrates" living "upon the sweat of their neighbor's brows." ${ }^{14}$ Although Livingston was apparently willing to accept paper money that was severely restricted to insure that it would not depreciate, ${ }^{15}$ the Constitution provided an even better solution by prohibiting the states from issuing any at all.

Livingston consistently thought that good government required virtue. British failure to maintain virtuous government was a factor justifying revolution. With a republic established, he thought that public virtue was essential and, during the war and afterwards, when he saw it missing he despaired for the continuation of the American experiment. In 1778 he pointed to the misuse of public funds for the war effort and lamented that "nothing but a miracle can save us, unless we resume our primitive Virtue! . . Good God! how different from the glorious Spirit with which we embarked in the Cause of Liberty." I6 In I 786 he thought that affairs were even more "gloomy" than "during the late war" because "We do not exhibit the virtue that is necessary to support a republican government." Something had to be done soon or independence "which has cost us so much blood and treasure to acquire" would be lost; the situation was "truly deplorable." ${ }^{\prime 7}$ The answer was a stronger government.

As governor of New Jersey, Livingston was severely restricted by the state's Constitution of 1776 , which gave most power to the legislature. This made it more difficult for him to aid the war efforts of the Confederation government, itself weak. As a result, he consistently supported

${ }_{13}$ Primitive Whig \#2, New Jersey Gazette, January 16, 1786; Primitive Whig \# 4, New Jersey Gazette, January 30, 1786; Primitive Whig \#5, New Jersey Gazette, Feb. 6, 1786.

${ }^{14}$ Primitive Whig \# 1, New Jersey Gazette, Jan. 9, I 786.

1s Sedgwick, 398. An exception was early in the Revolutionary War when he supported paper money. Thatcher, "Social and Economic Ideas," PNJHS v.6 I (I943), 44.

${ }^{16}$ Letter to Henry Laurens, President of Congress, quoted in Levine, 19. In a newspaper essay of the same year he wrote that "Whenever our public virtue decays, our government, which owes its origins to, and was founded upon, public virtue, will languish."

${ }_{17}$ Letter to William C. Houston, quoted in Sedgwick, 403. 
what he thought necessary to bolster the national government. ${ }^{18}$ After the Philadelphia Convention he pushed for ratification of the Constitution in the state. ${ }^{19}$ After hearing of ratification by the "crucial" eleventh state, Livingston rejoiced: "It was indeed [a] real joy to me, who have long been anxious to see a more efficient rational government than that of the confederation." ${ }^{20}$ In an address he congratulated the legislature on this event, concluding with "Thanks to God that I have lived to see it." ${ }_{21} \mathrm{He}$ hoped that the Constitution would bring "the re-establishment of public faith and private credit, of being respected abroad and revered at home" ${ }_{22}$ as well as "national happiness" and "prove a national blessing." ${ }^{23}$ Livingston died in 1790 before the results of the new form of government were apparent.

For all his reputation as a radical Whig, Livingston was a reluctant revolutionary. Although he ardently embraced the cause of independence (once it had been declared), he never gave up some of his "conservative" ideas. This included respect for property. As the war progressed he supported a more powerful executive and stronger national government. His dislike for paper money increased. When one adds to this the fact that New Jersey as a whole expected to benefit from the Constitution, it is not surprising that Livingston was in favor of the new document and, once it had been ratified, hopeful for the future.

\section{Paterson}

William Paterson was an immigrant brought to America by Irish parents who settled in Princeton and opened a store across the street from the young College of New Jersey (Princeton). He crossed the street to attend the college, overcame his humble origins, and rose to prominence in the state and nation.

At Princeton, Paterson pursued a classical education that included Greek and Latin, natural philosophy and rhetoric. He also gained a re-

${ }^{18}$ Sedgwick, 387. Levine, I48-1 52, 283, argues he even would have made Washington dictator with power to force the states to aid the war effort.

19 Sedgwick, 405; Carl E. Prince, William Livingston: New Jersey's First Governor (Trenton, 1976), I9.

${ }^{20}$ Letter to Dr. Joshua Lathrop, quoted in Sedgwick, 420-42 I. Although only nine states were needed for ratification, New York, the eleventh, was considered crucial because without it the country would have been split in two.

${ }^{21}$ Message to the legislature, ibid., $42 \mathrm{I}$.

${ }_{22}^{2}$ Prince, I 9.

${ }^{23}$ Klein, American Whig, 7 I 8-7 19. 
William Paterson

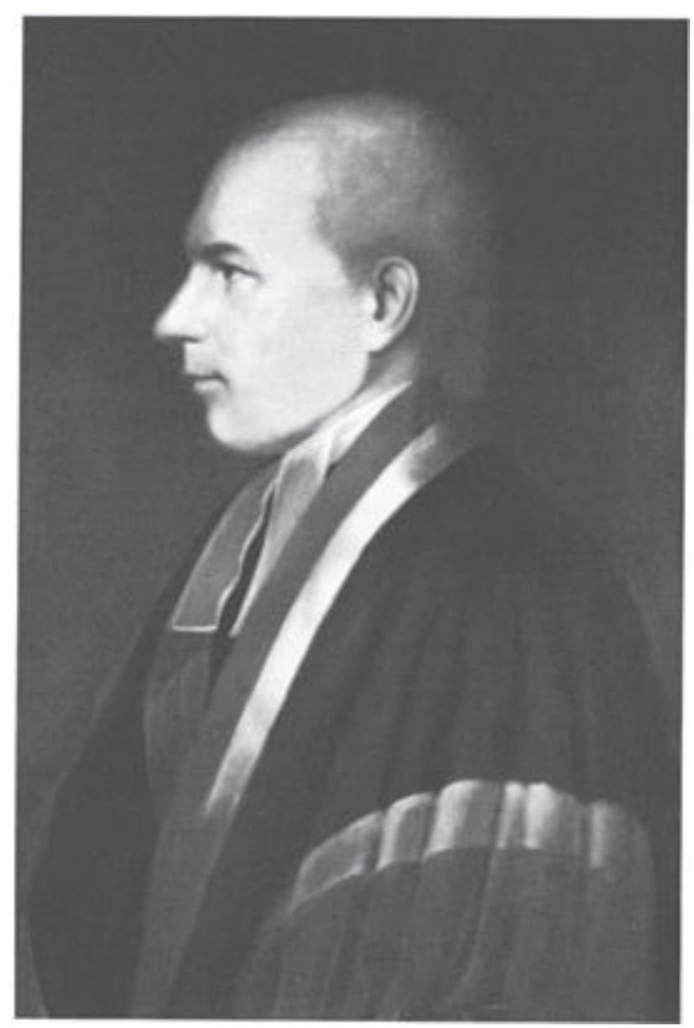

Special Collections and Archives

Rutgers University Libraries

spect for learning and later in life emphasized the importance of education because ignorance was the "mother of slavery" and "superstition." ${ }_{24} \mathrm{He}$ was particularly interested in literature and public speaking. At the time of the Constitutional Convention William Pierce described him as a modest man, "a Classic [classicist], a Lawyer, and an Orator." ${ }_{25}$ A eulogy in I 806 was more effusive:

He . . . possessed from nature a strong comprehensive understanding; a clear distinguishing judgment; an elevated imagination, and the powers of a commanding eloquence ... he has a native dignity and independence of mind. From his earliest years he was indefatigable in his application to literary pursuits. ${ }^{26}$

${ }_{24}$ MSS Essay \# 4, Rutgers University Libraries (RUL).

${ }^{25}$ Julian P. Boyd, "William Paterson Forerunner of John Marshall," in Willard Thorp, The Lives of Eighteen from Princeton (Princeton, 1946), I.

${ }^{26}$ Joseph Clark, A Sermon on the Death of William Paterson (New Brunswick, I 806), I 4. 
After graduating, Paterson studied law with Richard Stockton (a leading member of the New Jersey bar and future signer of the Declaration of Independence), and then opened a rural, and apparently sluggish, legal practice. It was with the Revolution that his legal and political careers took off. He was first elected to the New Jersey Provincial Congress and then, after Independence was declared, went on to become the state's first attorney general (a position he maintained throughout the war). In the I 780 os he tried to retire from politics to follow an increasingly lucrative legal business only to be drafted to serve first in the Constitutional Convention, and then the United States Senate. Upon Livingston's death in I 790 Paterson was elected governor; three years later he was appointed to the Supreme Court of the United States. Throughout his career Paterson remained a "conservative revolutionary" who used his pen in essays, and legal briefs, and to draft charges from the bench, to attack paper money while supporting public virtue and a stronger national government. ${ }^{27}$

Perhaps influenced by the atmosphere of Princeton (notorious for the number of patriots it produced), Paterson was an early supporter of American independence. He even went as far as to refuse to sign the 1776 Constitution of New Jersey because its concluding lines stated that the document would be null and void if differences with England were resolved. ${ }^{28}$ But this did not make him a radical or a democrat; "what Paterson wanted most was the assurance of law and order and the peaceful progress toward a nation of free citizens, led by a natural aristocracy." 29 He supported the Revolution, in part, as a protest to British corruption and moral degeneracy. In an address (c. 1775) he attacked the emphasis on "fashion," warned of the dangers from imitating England's "false glitter" and "refinements," preferring American "simplicity in manners and in dress." 30 He later emphasized that "republicanism delights in virtue." ${ }^{3 r}$

Paterson thought government should be balanced or "tyranny" would

${ }^{27}$ Paterson wrote numerous essays, most of which were published in the newspapers in the I 780 s and I 790 s. Dating these is, however, a problem. There are manuscript copies of the essays, primarily at RUL and Princeton (PUL), which are undated. Only scattered issues of newspapers for these years remain so further information is difficult to come by. See comments on essays, Richard P. McCormick, "Political Essays of William Paterson," JRUL v. 18 (1955), 38-49; and John O'Connor, William Paterson: Lawyer and Statesman 1745-1806 (New Brunswick, 1979), 307 n.44.

${ }^{28}$ Richard C. Haskett, William Paterson Counselor at Law (Princeton University Ph.D. thesis, I95 I), 99 .

${ }^{29}$ Boyd, 2.

${ }^{30}$ O'Connor, 13, 16, 62.

${ }^{31}$ MSS Essay \# 3 , RUL. 
result. ${ }^{32} \mathrm{He}$ distinguished between natural liberty and civil liberty; the second maintained order and followed law, for "Liberty implies the doing of what is right." 33 Thus for him with liberty came responsibility. Government, he consistently maintained, must support property rights. "Property ought to be secure, and rendered inviolate," he wrote, in order to encourage "Industry" "Honesty and good Faith." ${ }_{34}$ Furthermore, there should be no attempts to legislate equality of property because this would encourage idleness and sloth and be a "tax upon the active and industrious man." 35 At the same time he thought that nation the happiest where landed property "is fairly equally diffused among the people." When Paterson spoke of equality among men he did so meaning equal treatment before the law and equal opportunity; all citizens of the state "high and low, rich and poor . . . ought to be viewed with equal Eyes" and none be given preference by the law. ${ }^{36}$

Paterson himself profited from the Revolution, accumulating money and land (from confiscated estates) during its course. ${ }^{37}$ In addition, as a lawyer Paterson frequently represented creditors seeking repayment of debts. As a result, for both personal and philosophical reasons, he argued that debts should be repaid in money of the same value as borrowed. Paper money depreciated and the result was to take "from the Creditor, and put into the Pocket of the Debtor." For him the supporters of paper money were "idle, extravagant Wretches" who "live upon the Earnings of others" and "run in Debt." ${ }^{8}$ Money was not really scarce, as some thought, but rather was wasted by the legislature and by luxurious living, such as the purchase of "foreign Manufactures," consisting of "fashionable and expensive Amusements." 39 Further, Paterson argued in 1786 ,

32 "Address on Dissolution of Nations," PUL (transcription in RUL), np.

${ }^{33}$ Leonard B. Rosenberg, The Political Thought of William Paterson (New School of Social Research Ph.D. thesis, I 967), 46.

${ }^{34}$ Essay on Paper Money, RUL oversized (nd c. 1786). See also Van Horne v. Dorrance (1795) where he says "The preservation of property ... is a primary object of the social compact." For a similar statement made c. 1798 see Rosenberg, Political Thought, 48, 55.

${ }_{35}$ MSS Essay \# 3, RUL; James McLachlan, Princetonians $1748-1768$ (Princeton, 1976), 439-440.

${ }^{36}$ Rosenberg, Political Thought, 63 .

${ }_{37}$ Haskett criticizes Paterson for the way he, his friends and relatives, acquired property during the war stating that "his personal ethics ... left something to be desired"; 155 . O'Connor, disagrees, 47.

${ }^{38}$ Essay on Paper Money.

${ }^{39} \mathrm{He}$ also wrote "The indolent and dissapated [sic] may clamour about the Scarcity of Money; the one will not toil to get it, \& the other squanders it as fast as he receives; their clamour would be the same, if they possessed all the mines of Peru"; O'Connor, I 23-I 24. See also Boyd, 9. After the Constitution was adopted he reversed himself and said money had been scarce. 
everyone would be better off without it; people then would be compelled "to work for the bread they eat, and not to go about seeking whom they may devour." 40

From his wartime experiences as a peripatetic attorney general prosecuting Tories and others, he came to place high value on law and order. This led him as a legal scholar in the $\mathrm{I} 790$ os to expend considerable effort collecting, reducing, and revising the laws of New Jersey into a code most of which was then adopted by the state. The war also gave him a perspective from which to evaluate New Jersey's Constitution and the powers it gave the state's chief executive. What he saw he thought insufficient. A stronger governor could better protect property and enforce laws. ${ }^{4 I}$ The same attitudes carried over to his views of government under the Articles of Confederation.

Unlike Livingston, who faded into the woodwork at Philadelphia, Paterson stood out. When Edmund Randolph presented the "Virginia" plan to the Convention, Paterson countered with the "New Jersey" plan. Randolph's proposal scrapped the Articles of Confederation and provided for a new, stronger, central government with representation based on population. It clearly favored the large states. Paterson's alternative document revised the Articles of Confederation, rather than replaced it, by adding to the powers of Congress. Representation was still based on states, the mode preferred by New Jersey and the other small states. The differences between the two plans bitterly divided the delegates. In the debates Paterson refused to back down until the small states were protected by equal representation in the Senate. With this accomplished Paterson was satisfied, never having intended to push for states rights or a severely limited national government. ${ }^{42}$ Rather he, along with most New Jersey residents, favored a stronger central government as being in the best interests of the state. 43

The changes brought after I 789 were clearly to his liking. He wrote that "Before the adoption of the existing constitution of the United States,

40 $^{\circ}$ Essay on Legal Order, PUL (transcription RUL).

4' O'Connor, 84-86, 92-94.

${ }^{42} \mathrm{O}^{\prime}$ Connor convincingly argues that much of Paterson's stance in the Constitutional Convention was a political ploy; all along he was willing to accept less than he asked for as long as the small states were protected; I 14, I3 I-149. When reapportionment was considered by the Second Congress, Paterson used his influence (unsuccessfully) to try to keep the size of the House of Representatives down so that the large states would not overwhelm the small; ibid., 196-197. Rosenberg argues that Paterson's most extreme statements at the Convention represented the views of his constituents, not his own; Political Thought, 29-3 I, 38-39; see also Boyd, I 3 .

${ }^{43}$ Like Livingston he thought that New Jersey should have paid its requisitions to the Confederation government; O'Connor, 127. 
New Jersey was in a low and wretched situation." Trade went through New York and Philadelphia, the New Jersey legislature had resorted to the "mischievous system of paper money" so that credit was low, and money scarce. But with the Constitution "a wonderful change was visible in every class of men, and in every part of the State. Money became plenty [sic], confidence was restored, and credit placed on its proper basis; for contracts were rendered Sacred by the constitution, and paper-money was forever interdicted." He praised the "Great and glorious transition! Perhaps history does not afford an instance of the kind." 44 The Constitution, he exclaimed, was the source of "all our prosperity," "the ark of safety and the palladium of our liberties." 45

Once the Constitution was adopted Paterson supported the supremacy of the federal government and the idea of judicial review. This is particularly apparent in his decisions on the Supreme Court. For him the Constitution, "the work or will of the people themselves," was a fundamental law, "the sun of the political system," and above the legislature. His decisions supported the power of Congress, judicial review of state laws, and maintained that treaties were, like national laws, supreme. Explaining citizenship, he portrayed a duality stating "allegiance to a particular state is one thing; allegiance to the United States is another." .. . "The sovereignties are different." . . . "We have sovereignties moving within a sovereignty." In this relationship the national government was preeminent and its three branches were "co-ordinate" with none "subordinate." 46

From the time of the Revolution to the end of his life Paterson's ideas did not change much. As a youth he had written that luxury "effeminates and torments the opulent," "tempts the indigent," "turns the brave into cowards, and the industrious into thieves," while leading to "venality and dependence." 47 In the 1790 s he continued to oppose luxury, and also the speculation which became rampant at that time. Although clearly a Federalist, he never adopted the party label and indeed continued to oppose the idea of political parties, stating: "A person, who affects republican principles, and at the same time is a tool to party . . . is a pernicious character in a free government." ${ }_{48}$ Although he lived into the next century, his ideas, like Livingston's, tended to remain unchanged through the years.

44 MSS Essay \# 7 , RUL.

45 O'Connor, 162.

${ }^{46}$ Rosenberg, Political Thought, 48, I0I; Leonard B. Rosenberg, "William Paterson, New Jersey's Nation-Maker," NJH v.85 (1967), 30-31; O'Connor, 252.

47 "Address on Dissolution of Nations," np.

${ }^{48}$ Quote from Rosenberg, Political Thought, 76-77; see also MSS Essay \#2, RUL. 


\section{Stevens}

John Stevens was born into a prominent New Jersey family whose members were economic and political leaders of the colony. They were ship masters, merchants, and large landowners with seats on the East Jersey Board of Proprietors, and they also sat in the assembly and on the governor's council. Stevens attended King's College (Columbia University), and after graduating in I 768 , studied law with James Duane, an important New York attorney. During the Revolutionary War he served in the Continental Army, and as treasurer of the State of New Jersey. His interests were wide ranging and diverse, including progressive farming, and medical improvements. Although from I 787 to 1790 he exhibited a great interest in political debates and developments, his real fame in later years was as a naval architect, mechanical engineer, and promoter of the first railroads in the country.

Colonel Stevens became very wrapped up in the debate over the Constitution. In I 788 he even had short-lived political ambitions, suppressed when a "trial balloon" came to nought. ${ }^{49}$ But while politics was on his mind, he wrote a political pamphlet, authored a series of essays, which appeared in the New York newspapers, urging ratification of the United States Constitution, and drafted a proposed new constitution for New Jersey. Although less well known as an author of political tracts than Livingston, Paterson, or Witherspoon, he probably produced more literature specifically related to the Constitution than the other three put together. ${ }^{\circ \circ}$

Stevens' pamphlet, Observations on Government, long mistakenly attributed to William Livingston, has had an interesting history. ${ }^{5 \mathrm{I}}$ It was part of a series of interconnected works that began when the Baron Turgot, French philosopher and finance minister, wrote a letter to Richard Price, English radical and minister, that was published in $\mathrm{I} 784$. Turgot favored

${ }^{49}$ Letter to father, Dec. 4, 1788 , Stevens Family Papers, Reel \#9, letter to his father, December 23, 1788 , ibid.

5o This is an assumption based on available evidence. There are a number of essays written at this time to which no known author has been ascribed. Some could, conceivably, have been written by Livingston or Paterson. For examples see items from New Jersey Journal, December I 9, 26, I 787, and Trenton Mercury, November 6, 1787 in John Kaminski and Gaspare J. Saladino eds., Documentary History of the Ratification of the Constitution v.3 (Madison, I 978), I 46-I6I; V. I 5 (Madison, I 984), 559.

'I For proof of Stevens' authorship see Turnbull, 91; Richard P. McCormick, Experiment in Independence: New Jersey in the Critical Period ${ }_{1781-1789}$ (New Brunswick, 1950), $278-$ 279; and Joyce O, Appleby, An American Pamphlet in Paris (Claremont Graduate School and University Center Ph.D. thesis, 1966). The mis-attribution has led to several cases where Stevens' ideas are discussed as though they were Livingston's; see Dillon, I93; and Thatcher, "Political Ideas," 8 I-98, I 84-199. 
a unicameral legislature and a weak executive. He was countered by Jean Louis De Lome, a Genevan living in England, who, in The Constitution of England, defended English government as the best ever. John Adams joined the fray with his $A$ Defence of the Constitutions of Government of the United States of America, arguing for a bicameral legislature, and for balanced governments designed on the English example. Stevens' pamphlet was designed to refute both De Lome and Adams. The pamphlet was picked up and used two years later by French intellectuals who preferred the American to the English example. They started with what Stevens had written and added numerous footnotes and the text of the United States Constitution, expanding the volume to 29 I pages. Ironically, the pamphlet, in its enlarged French version, had a much larger impact in that country than it did in America. ${ }^{52}$

In context, Stevens' pamphlet belongs to the late eighteenth-century Atlantic communities' debate over political theory and constitutional forms, but its timing makes it part of the literary debate over the Constitution, particularly in New Jersey. The pamphlet was first advertised for sale in New York November 2, I 787, and excerpts from it appeared in the New York Daily Advertiser on November I 7, I787; early the next month Stevens was sending it to friends and relatives in New Jersey. ${ }^{53}$ Thus it was available to the members of the New Jersey Ratifying Convention (which met from December I I-I 8, I 787 ) including, of course, his father who presided over that meeting. ${ }^{54}$

Stevens began by attacking De Lome, Adams, and the English constitution. He was writing, he said, "in defence of our democratic form of government." 55 A balanced government (of monarchy, aristocracy, and democracy) was not necessarily best. Besides, English history showed that this did not always work, since that country frequently had been subject to disorders. Also, America did not have an aristocracy, and one was not likely to develop there. At the same time, direct democracy, where every-

52 See particularly Appleby, American Pamphlet; Documentary History v. 3 (Madison, I 98 I), 8 1-86. In France the title became Examen du gouvernement d'Angleterre compare' aux constitutions des 'Etats-Unis.

${ }_{53}$ Documentary History v.3, 145; Documentary History, v. I 3, 558-56r; Letter to his father, December 9, 1787, Stevens Family Papers, Reel \#9; Letter to his father, December 30, 1787 , ibid. The first letter was written just before the New Jersey Ratifying Convention met. In it he stated "I sent Col. Coxe a Pamphlet written by a Jersey Farmer, please to read it and let me know how you like it."

${ }_{54}$ Turnbull correctly points out first that it is impossible to prove the pamphlet influenced members of the New Jersey Convention, and secondly that since they were strongly in favor of the Constitution such influence was not necessary. See Turnbull, 94 .

ss Observations on Government, 7. 


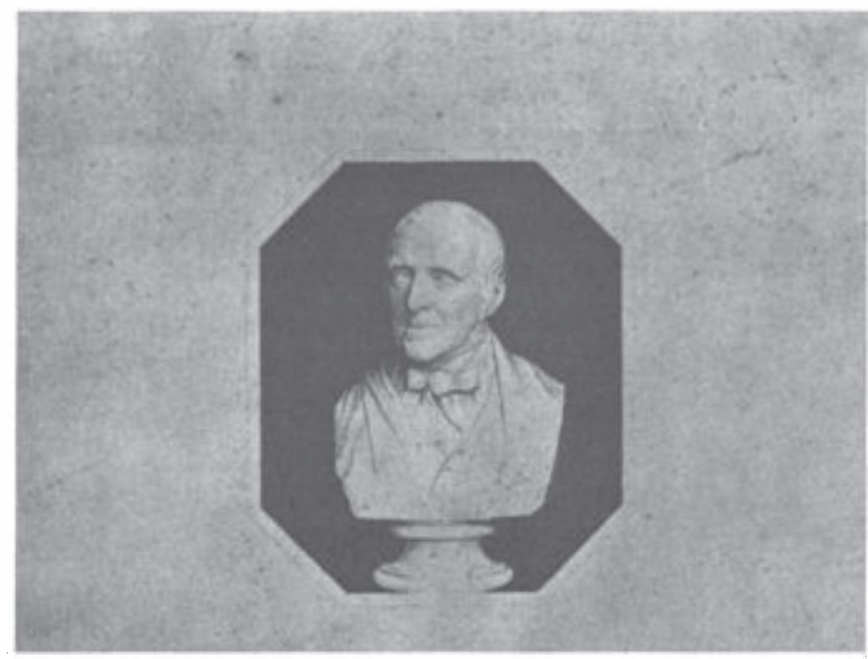

Colonel John Stevens

Special Collections and Archives Rutgers University Libraries

one was "entitled to a personal vote, in the administration of government," was neither good nor practical in America. ${ }^{56}$ Representative government was better; this and trial by jury were inheritances from England to be treasured. In other words, Stevens urged his readers to forget about balancing monarchy, aristocracy and democracy. In America the first two were missing, the third alone existed, and democracy would work as long as appropriate limits were placed on it.

Looking for a mechanical comparison to illustrate the best government, Stevens utilized a "jack" or roasting spit which, due to the addition of a flyer, continued to operate even when loaded unevenly. He continued: "in government the weight or origin of power, is the people, and the people only; the jack is the machinery of the government; the motions of which are regulated by adding a check or a flyer." 57 A government with checks on the people was best. One way of providing such a check was to

s6 Observations on Government, 34. Also 36, "The people ever have been, and ever will be unfit to retain the exercise of power in their own hands; they must of necessity, delegate it somewhere; hence the immense importance of those admirable contrivances which the English have had the honor of inventing and adopting; viz. a representative legislature, and a trial by jury."

57 Ibid., 3 I-32. 
have a two-house legislature, another was to have separate executive and judicial branches; these would reduce "the mischiefs of blind passions." 58 Where this had been done, American state governments were stable, the most democratic "that ever existed anywhere," and "approach near perfection." 59

Stevens concluded his pamphlet by pointing to the new plan from the Philadelphia Convention which, he said, "surpasses my most sanguine expectation." Adoption of this Constitution would lead to the envy and admiration of the world because it would prove "THAT MAN IS ACTUALLY CAPABLE OF GOVERNING HIMSELF." 60 He then proposed three amendments to make the document even better-that the executive be divided into three departments (president, chief justice, and superintendent of finance); they should make all appointments and jointly review the laws; the chief justice and superintendent of finance should serve on good behavior to be independent of "all popular influence" and capable of opposing Congress. ${ }^{61}$

Stevens did not rest his efforts with this lengthy pamphlet. In addition he wrote a series of essays for the New York Daily Advertiser which started November 2, I 787 and continued for two months. They were concurrent with numbers of the Federalist Papers (sometimes appearing in the same issue of the newspaper), and, in December, with the New Jersey Ratifying Convention. ${ }^{62}$ In them Stevens specifically took issue with the antifederalist author "Cato" and forcefully defended the Constitution. ${ }^{6}$ Both Cato and Montesquieu (quoted by Cato) were wrong that a republic could exist only in a small territory. ${ }^{64}$ Furthermore, Stevens felt that quoting authorities was not helpful, because the "path we are pursuing is new, and had never before been trodden by man." All that was necessary was that the powers of government be delegated, and that there be representation (rather than direct democracy). In fact he argued "that by appointing

${ }^{8}$ Ibid., 39.

s9 Ibid., 52.

6o $\mathrm{Ibid}$., 53 .

6. Stevens apparently thought amendments should be made after adoption. He later wrote to his father: "The Constitution must either be wholly received or wholly rejected. It is in vain to expect that any kind of federal government can ever take place, if the State Conventions are to make amendments." Letter of Dec. 9, 1787, Stevens Family Papers, Reel \#9.

62 See especially "Americus" essays of Nov. 2, 23, 30, Dec. 5, I 2, I 787.

6. Cato is supposed to have been either George Clinton, governor of New York, or Abraham Yates, Jr., New York delegate to the Constitutional Convention who did not sign the document. Documentary History v. I 3, 255.

${ }^{64}$ Stevens even said that if Montesquieu had "been an American, and now living, I would stake my life on it, he would have formed different principles." Americus, Nov. 2, I 787. 
Representatives, the people can have the business of the State transacted in a better manner than they can possibly do it themselves, there is then no determining what may be the extent of the state." 65

Continuing, Stevens argued that in this large republic, with the Constitution, factions will prevail less. ${ }^{66}$ Further he maintained the country needed a vigorous national government, and a strong executive. What was not crucial was virtue. Here Stevens had a different tone and emphasis than Livingston, Paterson, or Witherspoon. He even argued that because this government did not require the heroic virtues of the ancient Greek and Roman republics, it would last longer. Ambition, not virtue, is the "very life and soul of Republican Government," what sets "its wheels in motion." Under the Constitution men of ability could aspire to office, even to the presidency; this opportunity, open to all citizens "without distinction, is a perfection in Republican Government, heretofore unknown and unprecedented." 67

The Constitution should be adopted even though some people were opposed; Stevens asks, "should an Angel come down from Heaven, and present us with a Constitution of Government altogether spotless and free from blemish; should we not still have malcontents amongst us? Would there not be Cato's and Brutus's ready to disseminate groundless jealousies and vain fears?" 68

In a letter to his father written before these essays, Stevens had predicted that the Constitution would be ratified even in New York where there was considerable opposition; New Jersey he wrote, accurately, "will not boggle about it." The letter added a reason for support not mentioned in his pamphlet or essays, namely, improvement of the economic situation: "A Pamphlet published at Phila. says landed property will be worth 50 per cent more the day it is adopted." 69 A year later he saw another benefit, maintaining that the "credit and reputation of our new federal government will undoubtedly induce numbers of foreigners to settle among us." 70

${ }_{65}^{6}$ Americus, Nov. 30, 1787.

${ }^{66}$ The most famous argument along these lines is James Madison's Federalist \# IO. William Paterson also pointed to the same consequences of the Constitution. See essay published in McCormick, "Political Essays," 47; Rosenberg, Political Thought, 76.

${ }^{67}$ Americus, Dec. I 2, I 787 . In a later letter he did point out that the "success of the new constitution will depend very much upon the wisdom and virtue of the men who set it in motion. According to the direction they may happen to give it, its future operations may become mischievous or salutary." Turnbull, 99.

${ }^{68}$ Americus, Dec. 5, 1787.

69 Letter of October 27, 1787, Stevens Family Papers, Reel \#9.

${ }^{70}$ Letter to speaker of Assembly, November 24, 1788. Stevens Family Papers, Reel \# 9. 
Because Stevens thought that a "well ordered government, energetic yet not tyranical, free yet not licentious, is of all human blessings the greatest," he also proposed a new Constitution for New Jersey. The state, he felt, had everything "but a Good Government." ${ }_{71} \mathrm{He}$ would strengthen the powers, and lengthen the term, of the governor and provide for the election of qualified men who were known to the people and elected by a majority vote.

Like Livingston and Paterson, Stevens was essentially conservative. But for all the limits he wanted government to place on the people, he was much more of a democrat. In his idea that a virtuous people was not crucial in a republican government designed with constraints (and provided with wise and virtuous leaders), he clearly looked ahead rather than back. He did not worry about the evils of luxury. It is appropriate that Stevens alone lived well into the next century and actively participated in its commercial developments.

\section{Witherspoon}

John Witherspoon was born in Yester, Scotland and educated at the University of Edinburgh at the height of the Scottish Enlightenment. $\mathrm{He}$ continued his studies and became a Presbyterian minister and one of the leaders of the "Popular Party" in the Scottish church. As such, Witherspoon actively engaged in the ongoing pamphlet war with the "Moderate Party" (sometimes writing with an invective similar to Livingston). The two sides disagreed over the proper relationship between ministers and congregants and over practices of church members. In this controversy party names were misnomers, and Witherspoon's faction was actually the conservative one. ${ }^{72}$

In 1768 Witherspoon was persuaded by American Presbyterians to accept the presidency of the College of New Jersey (Princeton). Once in New Jersey he did three things, each of considerable importance: he served to reunite the American Presbyterians who had been divided by issues raised during the Great Awakening; he invigorated and helped secularize the curriculum of Princeton; and he actively participated in American politics, becoming "the most zealous Whig leader in the province."

"Drafts in Stevens Family Papers, Reel \#9. See also Turnbull, 98-99.

${ }_{72}$ George E. Rich, John Witherspoon: His Scottish Intellectual Background (Syracuse University Ph.D. thesis, 1964), I 31-1 33; Roger J. Fechner, The Moral Philosophy of John Witherspoon and the Scottish-American Enlightenment (University of Iowa Ph.D. thesis, I974), I I 9-I 22.

${ }^{73}$ Larry R. Gerlach, Prologue to Independence: New Jersey in the Coming of the American Revolution (New Brunswick, 1976), 222. 


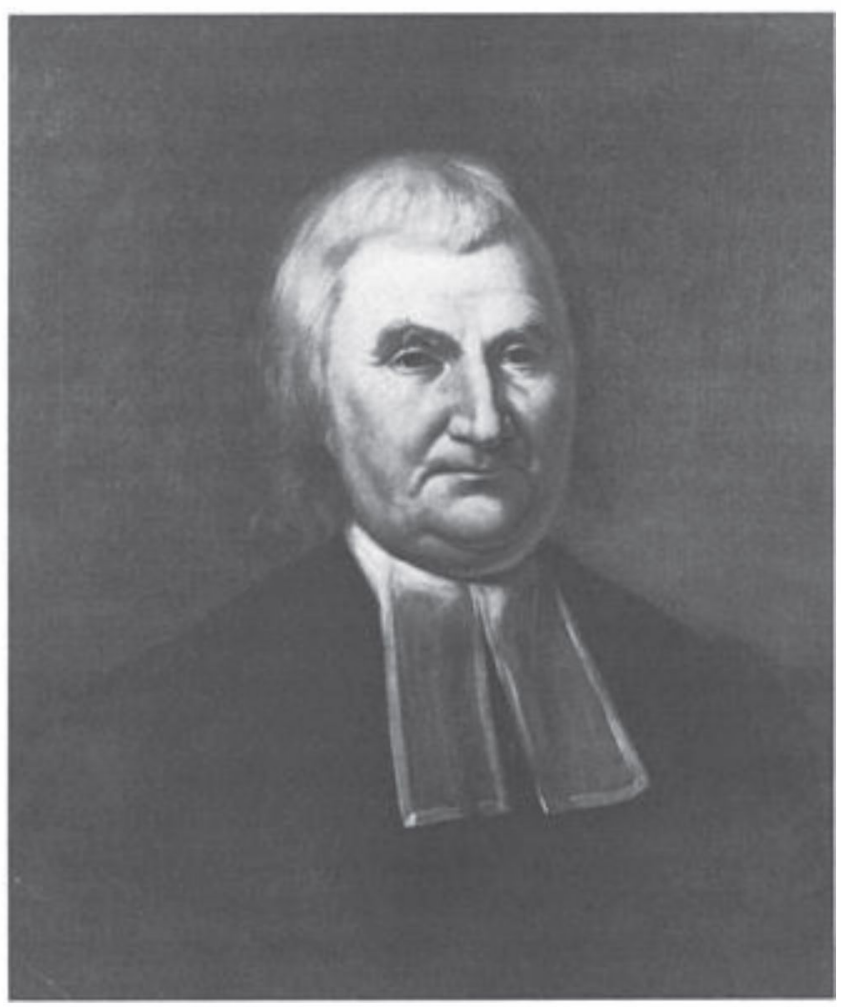

John Witherspoon

Special Collections and Archives Rutgers University Libraries

In all of this he has often been regarded as a radical - a British general described him as a "political firebrand, who perhaps had not a less place in the revolution than Washington himself. He poisons the minds of his young students and through them the Continent." 74 But Witherspoon had not changed all his spots on moving across the Atlantic. ${ }^{75}$ For all of his fiery advocacy of independence, this intellectual divine was as much a "conservative revolutionary" as Livingston, Paterson, and Stevens.

${ }^{74}$ Sir Guy Carleton quoted in Henry L. Savage, ed., Ashbel Green, The Life of the Revd John Witherspoon (New Jersey, 1973), 2.

${ }_{75}$ Although still basically conservative he did moderate some of his views on religious questions. See: Rich, I 5 I; Richard B. Sher, Church and University in the Scottish Enlightenment: The Moderate Literati of Edinburgh (Princeton, 1985), I6o. 
As minister, college president, and teacher, Witherspoon was deeply involved in learning and education. He studied the classics, knew Greek, Latin, Hebrew, and French, and read political theorists. He taught eloquence, composition, theology, and moral philosophy (which included ethics, philosophy, and history). Although not personally well versed in science, he saw to it that more of this subject was added to the curriculum. Unlike Livingston and Paterson he was not particularly interested in literature. His early opposition to plays and the theater was only slightly modified in later years. Still, his emphasis was on a broad education. A clergyman, he maintained, "should be a man of liberal knowledge, and fit for the conversation and society of men of rank and letters." 76

Witherspoon never wrote a political treatise. In addition, his early papers were destroyed by the British, his later ones by his second wife. 77 But scraps of his thinking remain in surviving essays, lecture notes, and bits of correspondence. From these it can be surmised that Witherspoon was an eclectic rather than original thinker. He combined the ethics and political ideas of the Scottish Common Sense school with the theology of Calvinism, mixing reason with revelation. For him man was a social animal, government was formed by contract, revolutions were justified for proper cause, property rights should be protected, and mixed government was best. In other words, he subscribed to the whole panoply of ideas traditionally associated with the Whig tradition in America. The only possible difference was the weight he gave to the God he saw behind it all. ${ }^{78}$ Inalienable rights came from God, while the social differences between men resulted from "the various stations in which God hath thought fit to place us." ${ }^{\prime 9} \mathrm{He}$ thought that one of the roles of ministers was to promote religion among people in order to increase their virtue. ${ }^{80}$

An early advocate of independence, Witherspoon was chosen to represent New Jersey at the Continental Congress in 1776 . He arrived just in

${ }^{76}$ Quote from Sher, I60. See also Richard M. Gummere, "A Scottish Classicist in Colonial America," Pub. Col. Soc. Mass. v.25 (1944), I46-I6I; Fechner, I65-I69; Thomas J. Wertenbaker, "John Witherspoon [1723-1794]: Father of American Presbyterianism; Maker of Statesmen," Eighteen from Princeton, 84; Francis L. Broderick, "Pulpit, Physics, and Politics: The Curriculum of the College of New Jersey, I 746-1 794," WEMQ S.3 v.6 (1949), 5868.

"7 Lyman Butterfield, John Witherspoon Comes to America (Princeton, 1953), ix-x; Varnum L. Collins, President Witherspoon: A Biography (Princeton, I 925) v. 2, 3, 199, 235.

${ }^{8}$ Fechner, The Moral Philosophy; Harry W. Fitzpatrick, The Political Philosophy of John Witherspoon (Rutgers University MA thesis, I95 I).

${ }^{79}$ Rich, 139.

${ }^{80}$ After the Revolution Livingston (previously anticlerical) also saw the clergy's role in promoting morality and virtue as a source of salvation for the republic; Levine, 249. 
time to cast his vote in favor of the Declaration. This was a decision he defended on the ground that anything else would have led to "the total and absolute ruin of the colonists. They would have been no better than tributary states to a kingdom" that was far away. ${ }^{8}$. But even then there were limits to his radicalism. He had no use for John Wilkes and his "shameless gang" of followers in England who were fighting for freedom of the press and a broader electorate. ${ }^{82}$

Witherspoon served in Congress on and off from 1776 until 1782 (and sat on 120 committees). As a member he consistently supported measures that would strengthen the central government. These included adoption of the Articles of Confederation, maintaining the credit of the central government, and the ceding of western lands by the large landed states to the nation as a whole. The last was a cause particularly dear to the heart of New Jersey residents and one of the reasons behind their support of the Constitution. On this issue Witherspoon maintained that at the moment of independence the lands passed from the crown to the new nation, rather than to the individual states. At the same time he thought that the states should retain their equal status within the Confederation. ${ }^{83}$

Witherspoon, like Livingston and Paterson, added his two cents to the debate over paper money in the 1780 os. But his tone was milder and his arguments more cautious. He warned that paper money which was made legal tender for debts "is a matter of great delicacy and danger." He then traced the historical development of money from barter, to "signs," to gold and silver, to paper. Metals were best because they were valuable, rare, portable, divisible, and durable. Paper was not "properly speaking money at all," and legal "tender laws, arming paper, or any thing not valuable in itself with authority, are directly contrary to the very first principles of commerce." Paper causes inflation, and makes metals disappear. He compared it to filling "a vessel brim full, making half the quantity water and the other oil, the last being specifically lightest, will be on the top, and if you add more water, the oil only will run over, and continue running till there is none left." However, Witherspoon was willing to accept paper money if it was not legal tender, was issued by

${ }^{8 r}$ Witherspoon, "On the Controversy about Independence" (I776), in The Works of the Rev. John Witherspoon (Philadelphia, I 801) v.4, 205-208.

${ }^{82}$ Witherspoon, "On Conducting the American Controversy" (1776), Works v.4, 211.

${ }^{83}$ "Speech Upon the Confederation," Works v.4, 253-257; "Speech on Finances," ibid., 259-266; "Speech on Motion for Paying the Interest of Loan-Office Certificates," ibid., 239244; John Rogers, The Faithful Servant Rewarded: A Sermon Delivered at Princeton (New York, I 795), 35; Collins, 4-9, 73, 77-79; Martha L. Stohlman, John Witherspoon: Parson, Politician, Patriot (Philadelphia, 1976), I 38. 
banks rather than governments, given for mortgages on land double the value of the loan, printed in high denominations, and retired in 15 years. ${ }^{84}$

The Constitution solved the money question. Witherspoon, who served in the New Jersey Ratifying Convention, approved of the new document. ${ }^{85}$ However, in a pamphlet which appeared about three years later, he confined his comments to the proposal for a new federal capital. Others in New Jersey urged this in the hope that Trenton would be the site selected, but not Witherspoon. He thought it was unnecessary, unprofitable, and unseasonable. He wrote that there was "reason to fear that it may be very hurtful" because it would produce heated debates. But most of all he thought the country should concern itself with paying off the public creditors, rather than with plans for an expensive city. ${ }^{86}$ Old Whig that he was, Witherspoon thought this an unnecessary luxury. He had always been a man plain in his attire, simple in his tastes, but large in his passions and willing to speak his mind. One only wishes that he had left more comments specifically on the Constitution.

\section{Conclusion}

Livingston, Paterson, Stevens, and Witherspoon were all "conservative revolutionaries" strongly in favor of the Constitution. They were "Federalists" from a mixture of philosophical and practical reasons. To them the Constitution would provide a "balanced" government, not giving too much power to the people or to any one branch of the government. It created a more powerful central government while protecting the small states. The president would be a stronger executive. In addition, they hoped the Constitution would insure the ceding of western lands, as well as improve commerce. On these issues, and therefore on the question of the benefits of the Constitution for their state, most residents of New Jersey agreed with the four men. Livingston, Paterson, and Witherspoon also wanted the Constitution because it would end the paper money question and protect private property. Here there had been disagreement in the state. A "radical" legislature, submitting to public pressure in I 785 I 786, had adopted paper money. But when it came to ratification the hatchet was buried. A stronger national government, with the power to

${ }^{84}$ Essay on Paper Money as a Medium of Commerce by a Citizen of the United States (Philadelphia, 1786 ).

${ }_{85}$ Collins, v.2, I 92 ; Green, 173.

86 "A Few Reflections Humbly submitted to the Consideration of the Public in general, and in particular to the Congress of the United States" [c. 1790], Works v.4, 23 I-237; Fitzpatrick, 53-54. 
tax all states fairly, was in the interest of everyone in the state. This was more important than paper money.

None of the four were "democrats" in the modern sense of the term. Stevens was the youngest and clearly the most "liberal" in the amount of power he would concede to the people. All four were republicans. But while in 1776 "republican" meant one who favored government by the people without a king, by 1789 the word had taken on added and different meanings. ${ }^{87}$ "Classical" republicans looked to the ancient republics of Greece and Rome as models for America. They felt that the maintenance of public "virtue" was absolutely essential for a modern republic to survive. Another necessary ingredient was "balance"-if not between monarchy, aristocracy, and democracy then at least between the social orders of society or between a natural aristocracy and the people at large. Livingston, Paterson and Witherspoon were classical republicans. They constantly harped on the need for virtue and attacked luxury. "Liberal" republicans were less inclined to look to the past. Virtue was praiseworthy, but not essential. Self interested, ambitious, individuals given freedom would end up serving themselves and the public welfare. Balance in government was less important. The size of the country need not be limited. Stevens was a liberal republican. He was the voice of the future and therefore it is particularly interesting that of the four he had the most to say about the Constitution, and the least about the need for "virtue."

Taken altogether, their pamphlets, essays, and comments indicate a broader and more extensive response, in New Jersey, to the issues of the period and to the Constitution itself than might otherwise be expected. New Jersey and its intellectuals may indeed have been unanimous in their approval of the Constitution, but they were not unthinking. At this particular juncture they thought, thought alike, and agreed. It was a rare moment in New Jersey history.

${ }^{87}$ Gordon S. Wood, The Creation of the American Republic $1776-1787$ (Chapel Hill, I 969), 46-90, 606-6I5; Lance Banning, "Jeffersonian Ideology Revisited: Liberal and Classical Ideas in the New American Republic," WE $M Q$ S.3 v.43 (1986), 3-19. 